\title{
Efficacy Of Insecticidal Sprays Control Of Insect Pests On The Growth And Yield Of Okra At Vinde - Fufore, Adamawa State, Nigeria.
}

\author{
*Samaila, A. E. and ${ }^{2}$ Oaya, C. S. \\ *Department of Agronomy Faculty of Agriculture, Federal University Kashere P. M. B. 0182, Gombe, Nigeria \\ ${ }^{2}$ Department of Agricultural Technology Adamawa State College of Agriculture P.M.B.2088, Ganye, Adamawa \\ - Nigeria
}

\begin{abstract}
The effect of Sherpa plus (Cyprnethon $12 \mathrm{~g}+$ diamethoate $100 \mathrm{~g} / \mathrm{l}$ ) on Okra on the yield of foliage and fruit was evaluated on tall and short cultivars of Okra at Vinde-Fufore, Adamawa state in Nigeria. A split plot design was used with three replications. Average yield of fresh foliage on sprayed plots were $6,176.02 \mathrm{~kg} . \mathrm{ha}$ (2011) and 5,897.5kg/ha (2011) on tall Okra cultivar, while $2660.85 \mathrm{~kg} / \mathrm{ha}$ (2011) and $3037.7 \mathrm{~kg} / \mathrm{ha}$ was obtained on short Okra cultivar. Lower yield of less than $1.400 \mathrm{~kg} / \mathrm{ha}$ was obtained in both years on the varieties of Okra. Yield of fresh fruits on short Okra in both years averaged 5,831 kg/ha and tall Okra 2,564.0kg/ha on sprayed plots while less than 1,000kg/ha was obtained on unsprayed plots. Short cultivars gave about 1,600kg/ha in both years on unsprayed plots. Major insect pests include Podagrica spp, Nisotra dilecta, Aphis gossypii, Dysdercus spp, and mealy bugs from early to late stage of crop growth. Results obtained showed that, sherpa plus is very effective in controlling insect pests of Okra.
\end{abstract}

Key Words: Okra, Yield, Insect Pest, Yield, Insecticide, Sprays, Cultivar

\section{Introduction}

Okra (Abelmoschus esculentum) is a crop grown throughout northern Nigeria, but commercial production is concentrated in Northeast region where it can be grown all year round under irrigation and rain fed. Historically, relatively few insecticides and miticides have been registered for use on okra making it difficult to manage insect and mites effectively. Recently, okra has been added to the Fruiting Vegetables Crop Group (tomatoes, peppers, eggplant) Webb, (2010). Cabbage looper and corn earworm can also bore into pods. Scouting for these pests is essential because the pesticides available (Bacillus thuringiensis products, spinosad, and methoxyfenozide) are most effective on young caterpillars and are less effective on later stages that can defoliate plants. Melon aphid, green peach aphid, and whitefly can be very damaging.

Products containing neem or azadirachtin can be used for all pests of okra but are generally only moderately effective. Because of limited options for chemical control of insects, conservation of natural enemies is important and possible. As with all crops, destruction of the crop after harvest can help reduce pest populations (CAB, 2000).

Okra plants are subject to attack by flea beetle (Podagrica puncticollis, P. pallida) infest the seedlings and can cause damage of economic importance by feeding on the leaves. If more than 2-3 individuals appear per seedling, the chemical control measures should be initiated. However seed dressing is also recommended. White flies (Bemisia tabaci), Jassids (Empoasca lubica) and Aphids (Aphis gossypii) attack okra also. Pods and flowers are primary targets of spiny bollworm (Earias insulanaa), while the caterpillar of the cotton bollworm (Heliothis armigera) prefers the reproductive parts of the plant, including buds, flowers and fruits. Control measures against this pest are only recommended in intensive production areas (Dankhar and |Sigh, 2013).

The cotton aphids A. gossypii (Homoptera: Aphididae) is found in many countries with tropical, subtropical and temperate climates. However its optimum environment lies in areas with higher temperatures. Insect pests constitute loses in yield and quality either directly by feeding or indirectly as vectors of plant disease and sometimes loses can be extremely serious and results to total yield loss on unsprayed field (Oaya and Samaila, 2013). Practically, Okra appears to be attacked by flea beetles, especially Podagrica spp. As a result, the quantity of the leaf tissues destroyed appeared to be heavy (Steve and Katayama, 2012). This particularly important vegetable, which is becoming a major economic crop especially in northern Nigeria, is however neglected. It is against this background that this study was carried out to investigate the effect of insecticidal sprays on yield of two popular cultivars in Vinde-Fufore, Nigeria.

\section{Materials And Methods}

The experiment was conducted at Benue Valley Farms Vinde-Fufore Local Government Area of Adarnawa State, Nigeria. Vinde is located within latitude $9^{\circ} 16^{1}$ North, longitude $12^{\circ} 391$ East at an altitude of 
158 .5rn above sea level, within the Northern Guinea Savannah ecological zone of Nigeria (Adelayo, 1999). The field experiment was conducted in 2011 and 2012 rainy seasons to evaluate the effect of chemical insect pest control. It consisted of two treatments of applying sherpa plus at the rate of 800 rnlha and a control and 2 cultivars of Okra. The experiment was laid out in split plot experimental design with the cultivars (tall and short) occupying the main plot and the insecticidal treatments the sub-plot. Plot size was $12 \mathrm{~m}^{2}$ ( $\left.3 \mathrm{~m} \times 4 \mathrm{rn}\right)$, with an inter-row spacing of $75 \mathrm{~cm}$ by $50 \mathrm{~cm}$ intra-row spacing. The experiment was replicated 3 times. Planting was done on the 5th of July, in 2011 and 2012, after a good land preparation. Two manual hoe-weeding was conducted, each one was followed by fertilizer application of NPK at the rate of $45 \mathrm{~kg} \mathrm{NPKha}^{-1}$ (Colditz, et al., 2012).

Eight (8) weeks after planting the insecticide sherpa plus (cypermethrin $12 \mathrm{~g}+$ dimetholate $100 \mathrm{k}$ at the rate of $800 \mathrm{~m} \mathrm{ha}^{-1}$ was applied fortnightly from September when insect population was significant at vegetative stage of Okra development up to full maturity. Data collected were on plant height, number of braches per plant, fresh and dry weight of leaves and stems as well as fresh and dry weight of fruits. Differed types of insects were collected, on unsprayed plots and their pest status was determined on a scale of 1-3, where $1=$ little or not important; 2 = causes little and Occasional damage and $3=$ common and cause serious damage (Oaya and Samaila, 2013). The part of plant the insect pests were found and pest stage was recorded. These were taken from 5 randomly selected plants in each plot and averaged. The data was subjected to analysis of variance and (ANOVA) the least significant difference was used to separate the means.

\section{Results}

The effect of insecticide on plant height was significant on both Okra varieties in both 2011 and 2012 rainy seasons, where the sprayed treatments produced significantly taller plants of 1.64 and 1.55 for sprayed short and tall cultivars respectively as against 1.30 and 1.18 for unsprayed short and tall cultivars respectively in 2011 as shown in Tables (1, 2, 3, and 4). Similar pattern of plant height was observed in 2012. A similar trend was also observed with the number of branches even before flowering and at maturity as shown in Table 1, but the number of branches increased from 10-15 on short Okra in 2011 and same was also observed in 2012 from 15-23 branches per plant on tall Okra in 2011 on sprayed Okra. While lower value of $9-12$ branches was recorded on unsprayed tall Okra, and similar value of 10 - 18 branches on Okra in 2011. In the same vein, sprayed Okra plants gave significantly greater fresh and dry weight of both stems and leaves at maturity.

Results of the effects of variety and insecticidal sprays on fruit yield in Okra are presented in Table 2. The table showed that both fresh and dry fruit yields were significantly greater for the sprayed plants as compared to the unsprayed plants for both cultivars (tall and short) and across both seasons (2011 and 2012).

Insects however, constitute a serious menace on the yield of Okra, since unsprayed Okra showed significant difference in yield as compared to sprayed Okra. The major insecta found causing severe attack were the foliage feeders which are listed in Table 5. Podagrica unifbrma, Nisotra delecta and Aphis gossypii fall within the category 3, while Mealybugs, Dysdercus volkeri Monolepta duplicata, Asparvia armigera, Helicoverpa annigera, and grasshoppers fall under the mild attack and cause little or occasional damage. The conccinellid beetles, Exochomus flavipes, Cheilomenes sulphurea and Epilachna simils are found as predators on aphids, but E. similes is also found cutting holes on foliage occasionally.

Table 1: Interaction effects of insecticide and cultivar on plant height $(\mathrm{m})$ and number of branches before flowering and at maturity per plant of Okra at Vinde-Fufore in 2011 and 2012 cropping seasons.

\begin{tabular}{|c|c|c|c|c|c|c|}
\hline \multirow{3}{*}{ Treatment/variety of Okra } & \multirow{2}{*}{\multicolumn{2}{|c|}{$\begin{array}{l}\text { Plant height at } \\
\text { maturity }(\mathrm{m})\end{array}$}} & \multirow{2}{*}{\multicolumn{2}{|c|}{$\begin{array}{l}\text { No. of branches/ } \\
\text { plant before } \\
\text { Flowering }\end{array}$}} & \multirow{2}{*}{\multicolumn{2}{|c|}{$\begin{array}{l}\text { No. of branches! plant at } \\
\text { maturity }\end{array}$}} \\
\hline & & & & & & \\
\hline & 2011 & 2012 & 2011 & 2012 & 2011 & 2012 \\
\hline Tall Cultivar (Unsprayed) & 2.00 & 16.14 & 16.20 & 17.40 & 21.00 & 22.12 \\
\hline Short Cultivar (Sprayed) & 1.45 & 1.54 & 15.24 & 16.35 & 24.30 & 25.01 \\
\hline Short Cultivar (Unsprayed) & 1.20 & 1.31 & 10.47 & 10.50 & 22.50 & 22.45 \\
\hline
\end{tabular}

Table 2: Interaction effects of insecticide and cultivar on fresh and dry weight of stern and leaves at maturity at Vinde-Fufore in 2011 and 2012 cropping seasons.

\begin{tabular}{lllll}
\hline \multirow{2}{*}{$\begin{array}{l}\text { Treatment/variety } \\
\text { of Okra }\end{array}$} & \multicolumn{2}{l}{$\begin{array}{l}\text { Weight of fresh stem and } \\
\text { leaves at maturity }(\mathrm{m})\end{array}$} & \multicolumn{2}{l}{$\begin{array}{l}\text { Dry weight of leaves and } \\
\text { stem at maturity g/plant }\end{array}$} \\
\cline { 2 - 5 } & 2011 & 2012 & 2011 & 2012 \\
\hline Tall Cultivar (Sprayed) & 159.00 & 175.50 & 98.85 & 99.00 \\
Tall Cultivar (Unsprayed) & 79.00 & 85.20 & 65.20 & 65.50 \\
Short Cultivar (Sprayed) & 282.50 & 281.20 & 155.50 & 170.40 \\
Short Cultivar (Unsprayed) & 97.80 & 95.90 & 61.5 & 60.80 \\
LSD (0.05) & 19.52 & 2681 & 9.12 & 22.40 \\
\hline
\end{tabular}


Table 3: Interaction effects of insecticide and cultivar on fresh leaf yield before flowering and dry leaf yield

$(\mathrm{kg} / \mathrm{ha})$ at harvest of Okra at Vinde-Fufore in 2011 and 2012 cropping seasons.

\begin{tabular}{|c|c|c|c|c|}
\hline \multirow[t]{2}{*}{$\begin{array}{l}\text { Treatment/variety } \\
\text { of Okra }\end{array}$} & \multicolumn{2}{|c|}{$\begin{array}{l}\text { Fresh leaf yield before } \\
\text { flowering }\end{array}$} & \multicolumn{2}{|c|}{$\begin{array}{l}\text { Dry leaf yield before } \\
\text { flowering }\end{array}$} \\
\hline & 2011 & 2012 & 2011 & 2012 \\
\hline Tall Cultivar (Sprayed) & $8,276.02$ & $6,680.50$ & 950.80 & 1200.00 \\
\hline Tall Cultivar (Unsprayed) & 1412.50 & 1450.20 & 325.00 & 216.00 \\
\hline Short Cultivar (Sprayed) & 3980.50 & 3250.00 & 516.50 & 522.80 \\
\hline Short Cultivar (Unsprayed) & 1550.90 & 1350.00 & 275.00 & 258.40 \\
\hline LSD $(0.05)$ & 1525.1 & 1712.5 & 160.50 & 230.50 \\
\hline
\end{tabular}

Table 4: Interaction effects of insecticide and cultivar on fresh calyx yield before flowering and dry calyx yield (kg/ha) at harvest of Okra at Vinde-Fufore in 2011 and 2012 cropping seasons.

\begin{tabular}{|c|c|c|c|c|}
\hline \multirow[t]{2}{*}{ Treatment/variety of Okra } & \multicolumn{2}{|c|}{ Fresh Fruit } & \multicolumn{2}{|c|}{ Dry fruit } \\
\hline & 2011 & 2012 & 2011 & 2012 \\
\hline Tall Cultivar (Sprayed) & 2800.00 & 2750.60 & 950.50 & 1250.80 \\
\hline Tall Cultivar (Unsprayed) & 820.50 & 781.00 & 381.50 & 350.00 \\
\hline Short Cultivar (Sprayed) & 5450.00 & 5900.00 & 1650.50 & 1815.00 \\
\hline Short Cultivar (Unsprayed) & 1720.40 & 1812.00 & 650.20 & 600.40 \\
\hline $\operatorname{LSD}(0.05)$ & 550.40 & 1650.20 & 295.40 & 580.5 \\
\hline
\end{tabular}

Table 5: Insects found on Okra during 2011 and 2012 cropping seasons at Vinde-Fufore North Guinea Savannah of Nigeria.

\begin{tabular}{|c|c|c|c|c|c|c|c|}
\hline \multicolumn{2}{|l|}{$\begin{array}{l}\text { Scientific Names/ } \\
\text { (order: family) }\end{array}$} & \multirow{2}{*}{$\begin{array}{l}\text { Pest stage } \\
\text { Adult }\end{array}$} & \multirow{2}{*}{$\begin{array}{l}\text { Pest status } \\
3\end{array}$} & \multicolumn{4}{|c|}{$\begin{array}{l}\text { Parts of Plant found } \\
\text { Leaf shoot flower calyx }\end{array}$} \\
\hline $\begin{array}{l}\text { Podagrica Informa Jac. } \\
\text { (Colecoptera: Chyrsornelidea) }\end{array}$ & & & & $* * *$ & $*$ & $*$ & $*$ \\
\hline $\begin{array}{l}\text { Nisotra delecta Dahn, } \\
\text { (Colecoptera: Chyrsornelidea) }\end{array}$ & & Adult & 3 & $* * *$ & $*$ & $*$ & $*$ \\
\hline $\begin{array}{l}\text { Exochomus flavipes } \\
\text { (Colecoptera: Coccinellidea) }\end{array}$ & & Larvae Adult & Predator & $*$ & $*$ & $*$ & $*$ \\
\hline $\begin{array}{l}\text { Epilachna similes Thunb. } \\
\text { (Coleoptera: Coccinellidea }\end{array}$ & & Adult & Predator \& 1 & $* *$ & $*$ & $*$ & $*$ \\
\hline $\begin{array}{l}\text { Aphis gossypii Clover } \\
\text { (Homoptera: Aphididea) }\end{array}$ & & Nymphs \& Adult & 3 & $* * *$ & $* *$ & $*$ & $*$ \\
\hline $\begin{array}{l}\text { Mealybugs (Ferrisia Virgata) } \\
\text { (Heteroptera: Pseudococcidae) }\end{array}$ & & Nymphs \& Adult $2 \&$ & Vector & $* *$ & $* * *$ & $*$ & $*$ \\
\hline $\begin{array}{l}\text { Asparvia armigera Fab. } \\
\text { (Cheteroptera: Pentatomidea) }\end{array}$ & & Nymphs \& Adult & 2 & $* *$ & $* *$ & $*$ & $*$ \\
\hline $\begin{array}{l}\text { Grasshoppers of Various } \\
\text { (Orthoptera) }\end{array}$ & Species & Nymphs \& Adult & 2 & $* *$ & $* *$ & $* *$ & $* *$ \\
\hline
\end{tabular}
optera)

\section{KEY}

* $\quad$ No insect -little or not important

** $\quad$ Mild attack 2-causes little and malerate damage

*** Severe attack 3-common and causes serious damage

\section{D1cussion}

The results obtained clearly showed a significant difference in yield when sprayed with insecticide irrespective of the cultivar of Okra. The increased number of branches, and plant height significantly sowed, the more Okra yield is obtained, particularly the spayed Okra and this agrees with (Oaya, et al. 2012; Hill and Wailer, 1989), that the increased number of branches due to chemical spray as compared to the reduced number of sprays affects the yield of Okra.

One of the major factors affecting the yield of Okra is the insect pests. There were no insects visibly observed during the cause of experiment on the sprayed plots apart from the honey bee and wasp that appeared a. week after straying, which are beneficial insects as pest pollinators. This observation is in agreement with (Colditz, 2009 and Matthew, 1992). The major insect pests recorded were the flea beetles (Podagrica uniforma and Nisotra dilecta), which have caused serious menace on Okra as reported (Steve and Katayama, 2013).

These insects appear early in the season up till harvest period. Aphids are also serious pests of Okra which also causes severe attack, but the population could be considerably reduced by natural enemies, the coccinellid beetles, but the effect of insecticide also wipes out both pests and natural enemies. Although Oaya and Samaila, (2013) reported, that reduced insecticidal sprays, could also reduces the population of flea beetles, but the number of branches on the Okra is also reduced, which in turn affected yield as compared to spraying till when Okra matures. The results clearly showed that, the tall cultivar okra are good and better if its for the yield of foliage or if foliage production is the emphasis, but if Okra is to be cultivated for its fruit, the short cultivar 
Okra gives a better yield, and hence the choice, depends on the farmer as to plant either the tall or short cultivar. Moreover, observation shows that short cultivar produces a better and economical size fruits than the tall cultivar. The effect of Sherpa plus was effective on the insect pests of Okra which gave a better yield than when only cypermethrin, while this research used systemic and contact insecticide.

\section{References}

[1]. Adebayo, A.A. (1999). Introduction In: Adamawa State in Maps. A.A. Adebayo and M.L. TUKUR (eds) 112pp first Edition Paraclet Publisher, Vinde-Fufore, Nigeria.

[2]. CAB International (2000). Crop Protection Compendium on Roselle Production.

[3]. Colditz, P. Grandberry, D and Charles, V. (2009) Commercial Okra Production, Extension Horticulturist - Vegetable Crops. University of Georgia College of Agriculture and Environmental Sciences.

[4]. Dankhar, B. S. and Siggh, R. (2013) Okra Handbook: Global Production, Processing and Crop Improvement. HNB Publishing, UK, pp475.

[5]. Hill, S.W and Wailer, N.D. (1989). Tropical pests of West Africa. Macmillan Publishers Ltd. London pp. 310-420.

[6]. Matthew, G.A, (1992). Pesticides Application Methods $20^{\text {th }}$ edition. Longman Singapore Publishers (PTE) ltd p.3

[7]. Oaya, C. S. and Samaila A. E. (2013) Toxicity Potentials of Leaf Powders of Wild Lemon (Afreagle paniculate) and African Rock Fig (Ficus congensis Engl.) against the Cowpea Seed Bruchid (Callosobruchus maculatus Fab.) Journal of Agricultural Science Canadian Centre of Science and Education Technology. Vol. 5, No. 4. Pp 80 - 84. www.ccset.net/jas

[8]. Oaya, C. S., Malgwi, A. M. and Samaila, A. E. (2013) Insecticidal Efficacy of African Rock Fig Leaf Powder (Ficus congensis Engl.) against the Groundnut Bruchid (Caryedon serratus Olivier) on Stored Groundnut in Yola. IOSR Journal of Agriculture and Veterinary Science (IOSR-JAVS) Volume 2, Issue 1 (Jan. - Feb. 2013), PP 24 - 27 www.iosrjournals.org

[9]. Onwueme, I.C. and Sinha, T.D (1991). Field crop production in Tropical Africa: Principles and Practices. CTA Wageningen (Publishers) Netherlands page. 382.

[10]. Steve, I. and Katayama, R. W. (2012) Okra Production Update for Small Acreage Growers. Horticulture. Cooperative Extension Programme. University of Arkansas at Pine Bluff.

[11]. Tindall,. H. (1983). Vegetables in the tropics. Macmillan, London, United Kingdom 332-337 